\title{
Focus
}

\section{Prediking en predestinatie in Genève}

\author{
J. Hoek
}

Pieter L. Rouwendal, Predestination and Preaching in Genevan Theology from Calvin to Pictet [Studies in the History of Church and Theology, red. Andreas J. Beck, Leuven, dl. 1], (Kampen: Summum Academic Publications, 2017), 355 p., $€ 75,00$ (ISBN 9789491583995).

Dit en volgend jaar is het 400 jaar geleden dat in Dordrecht de nationale synode bijeenkwam die zo'n groot stempel heeft gezet op de verdere ontwikkeling van de naar Gods Woord gereformeerde kerken in de Lage Landen bij de zee. In ons tijdschrift zal daaraan ruime aandacht worden besteed. Dit Focusartikel kan worden gezien als een bescheiden voorproefje, omdat hierin aandacht wordt gevraagd voor de predestinatie, het leerstuk dat aan het begin van de zeventiende eeuw in ons land zoveel stof tot discussie opleverde en een scheur trok onder de gereformeerden. Hoe belijden we de verkiezende God, 400 jaar na 'Dordt'? Het hier besproken proefschrift van Rouwendal prikkelt tot deze bezinning, zij het vanuit een strikt historische invalshoek. Het kenmerkt zich door heldere probleemstelling, adequaat bronnenonderzoek en transparante opbouw. Wat Dordt betreft: er is in dit boek aandacht voor de afgevaardigden vanuit Genève naar de synode, Johannes Diodati (1576-1649) en Theodorus Tronchin (1587-1657). Diodati nam vanuit een infralapsarische benadering (de overheersende positie aan de academie van Genève na de dood van Beza) afstand van de visie van de supralapsariër Piscator, die leerde dat de verworpenen ter verdoemenis waren geschapen. En hij maakte ook geen geheim van zijn afkeuring van scherpe formuleringen gebezigd door Franciscus Gomarus. De inbreng van de afgevaardigden uit Genève in Dordrecht illustreert hoe de toenmalige academie van de stad aan het Lac Léman een middenpositie innam tussen enerzijds strikt supralapsarische theologen als Gomarus, Piscator en Maccovius, en anderzijds voorlopers van het hypothetisch universalisme, zoals de afgevaardigden uit Bremen en Engeland en tot op zekere hoogte ook de Waalse theologen zoals Daniël Colonius.

De onderzoeksvraag in deze dissertatie betreft de mate waarin en de wijze 
waarop de predestinatieleer de prediking in Genève stempelde in de periode van Johannes Calvijn (1509-1564) tot en met Benedict Pictet (1655-1724). Is er vooral continuïteit of discontinuïteit tussen de visies van Calvijn en zijn opvolgers? Is de inhoud van de preken van betrokken theologen consistent met hun systematisch-theologische uiteenzettingen? Hier hangt een cluster van vragen mee samen die de eeuwen door vele pennen in beweging hebben gebracht en tot niet zelden onverkwikkelijke kerkstrijd aanleiding hebben gegeven. Wat is de invloed van de predestinatieleer op de leer van de uitwendige roeping? Hoe kan God hen die Hij verworpen heeft welgemeend roepen tot het heil en hoe kan Hij rechtvaardig zijn in zijn oordeel over de ongehoorzaamheid aan deze roeping, wanneer de verworpenen daartoe door Hemzelf bestemd zijn? Zagen gereformeerde theologen in de tijd van de Reformatie en van de gereformeerde orthodoxie deze en aanverwante vragen onder ogen in hun academische werk? Hoe dachten ze over de taak van de predikant die niet weet wie van zijn hoorders verkoren of verworpen zijn? Waren zij van mening dat de predestinatieleer in de prediking moest doorklinken en zo ja, hoe? Wat is de verhouding tussen verkiezing en verbond? Hoe is de visie op de gemeente en op de uitgestrektheid van de verzoening? Hoe is de samenhang tussen de visie op predestinatie en die op het wezen van geloof?

De auteur beklemtoont telkens - in overeenstemming met de benadering in de school van Richard Muller c.s. - dat in de ontwikkeling van Reformatie naar gereformeerde orthodoxie vooral de continuïteit overheerst. Inderdaad toont hij aan dat er, ondanks verschillende eigen accenten of uitwerkingen, tussen bijvoorbeeld Calvijn, Beza en Turrettini veel meer overeenstemming is dan verschil. Terecht ook neemt hij herhaaldelijk afstand van standpunten die eerdere onderzoekers hebben ingenomen en die veeleer de discontinuïteit beklemtoonden. Over het algemeen acht ik Rouwendals betoog overtuigend en de conclusies gefundeerd. Toch zijn er wel enkele kritische vragen te stellen.

Alle besproken theologen gaan uit van een predestinatio gemina. Voor Johannes Calvijn is het, in polemiek met onder anderen Albertus Pighius en Hiëronymus Bolsec, duidelijk dat er een verborgen besluit van God is tot verkiezing en verwerping. Wie eeuwige verkiezing leert, kan niet vervolgens eeuwige verwerping ontkennen. Het een is met het ander gegeven. De redenen die God hebben gemoveerd om te besluiten zoals Hij besloten heeft, zijn voor ons verborgen, maar in het geloof belijden we dat deze redenen volstrekt rechtvaardig zijn. Omdat het offer van Christus meer dan voldoende (sufficienter) is tot verzoening van de zonde van de hele wereld, kan het evangelie aan iedereen vrijuit gepredikt worden met appel tot bekering en geloof. Dat betekent echter niet dat God onvoorwaardelijk zou willen dat iedereen behouden wordt. In dat geval zou het namelijk niet anders kunnen dan dat iedereen 
metterdaad gered wordt. Gods soevereine wil is immers niet te weerstaan. Het gegeven dat velen het evangelie afwijzen en dus niét gered worden, maakt volgens Calvijn duidelijk dat Gods wil gericht is op het behoud van de verkorenen voor wie het offer van Christus daadwerkelijk verzoenende kracht heeft (efficaciter). Dit denken vanuit Gods verkiezing staat in een zekere spanning tot het denken vanuit Gods verbond.

Theodorus Beza (1519-1605) verdedigt Calvijns predestinatieleer tegenover Heinrich Bullinger, die Calvijn ervoor had gewaarschuwd niet te stellen dat God de val had verordend en sommige mensen tot eeuwige verwoesting had geschapen en hen daartoe verblind. Zulke harde uitdrukkingen zouden volgens Bullinger God tot de Auteur van zonde en ongeloof maken. Beza stelt daartegenover dat de schuld van de zonde weliswaar aan de mensen zelf moet worden toegeschreven, maar dat deze schuld toch afhankelijk is van de verwerping die God heeft verordend tot zijn eigen eer in het straffen van de kwaaddoeners. Het ongeloof is wel de causa damnationis (oorzaak van de verdoemenis), maar niet de causa reprobationis (oorzaak van de verwerping), evenmin als het geloof de causa electionis is, want het geloof is juist vrucht van de verkiezing. Bullinger meende dat God niet de causa van de zonde kon zijn zonder dat dit zou impliceren dat ook de schuld, de culpa van de zonde bij God zou liggen, wat hij hartgrondig verwierp. Beza stelde echter in navolging van Calvijn dat weliswaar niet de culpa, maar wel degelijk de causa van de zonde uiteindelijk bij God ligt. Hoewel Beza zijn predestinatieleer voornamelijk in continuïteit met Calvijn ontwikkelt, zijn er toch enkele opmerkelijke verschillen aan te wijzen. Hij maakt geen gebruik van het concept van gradus electionis, verschillende stappen in de verkiezing op de lijn van algemeen naar particulier. Ook verwerpt hij in de verzoeningsleer het klassieke onderscheid tussen sufficienter en efficaciter. Onomwonden stelt hij dat Christus alleen voor de uitverkorenen is gestorven. In zijn Tabula vindt de aanwijzing van Christus als Middelaar strikt als uitvoering van het besluit tot verkiezing plaats. Beza vond het verwarrend en ongepast om te zeggen dat Christus voor de gehele wereld is gestorven. Naar mijn opvatting legt Rouwendal op dit punt in reactie op eerdere onderzoekers van de weeromstuit te veel nadruk op de continuïteit met Calvijn als hij stelt dat Beza eenvoudig verder ging in een richting die door Calvijn al impliciet was ingeslagen (125). Het kan immers wel degelijk ingrijpend zijn om een stap verder te zetten op een weg waar een voorganger halt hield of om consequenties te trekken waarvoor deze terugschrok.

Een volgend punt van verschil tussen Calvijn en Beza ligt in beider verbondsopvatting. Het genadeverbond strekt zich bij Calvijn breder uit dan de particuliere verkiezing en heeft daarom een voorwaardelijk element. Het verbond wordt in de tijd opgericht met allen die daartoe in meer algemene zin 
verkoren zijn, maar het is tot op zekere hoogte breekbaar, en wordt ook inderdaad gebroken door de verworpenen die de condities van het genadeverbond (geloof en bekering) niet vervullen, terwijl God zelf zorgdraagt voor de vervulling van die voorwaarden in de harten en levens van hen die in meer specifieke zin uitverkoren zijn. Men kan dus niet zeker zijn van het heil op basis van het opgenomen zijn in Gods genadeverbond. Wel wordt dit verbond door God gebruikt als een middel om mensen tot waar geloof, zekerheid en volharding te brengen. Het verbond is geen doel in zichzelf, maar een weg die naar het doel kan leiden en neemt zo een middenpositie in tussen persoonlijke verkiezing en verwerping of tussen redding en verdoemenis. Beza lijkt in zijn latere ontwikkeling al dan niet bewust afstand te nemen van de visie dat alle kinderen van de gelovigen (en niet alleen de uitverkorenen onder hen) tot het genadeverbond behoren. Zo komt hij uit bij een niet conditioneel en dus onverbrekelijk verbond waarin alleen de uitverkorenen opgenomen zijn. Is hierdoor het verschil in opvatting over het verbond tussen Calvijn enerzijds en Beza en Turrettini anderzijds toch niet ingrijpender dan de auteur doet voorkomen? Calvijn kan vanuit zijn verbondsopvatting de beloften van God onbevangen verkondigen aan heel de gemeente, terwijl dit bij Beza niet het geval is. Rouwendal wil niet weten van de kwalificatie dat het verbond bij Beza en zijn opvolgers onder de beheersing van de verkiezing komt te staan. Maar is dat toch niet het geval wanneer het verbond in wezen tot de uitverkorenen wordt beperkt, terwijl vele gedoopten slechts deelhebben aan de bediening van het verbond?

Een klemmende vraag die rijst bij het nadenken over de door de Geneefse theologen ingenomen posities, is die naar Gods intentie met de prediking van het evangelie. Het is mijns inziens dringend nodig om op dit punt de gedachten van de in dit boek besproken auteurs opnieuw te ijken aan het beeld van God dat ons in de Schriften wordt getekend. Zo weerspreekt Calvijn de opvatting van Pighius dat het Gods bedoeling met de prediking zou zijn dat allen die het evangelie horen behouden worden. Hij stelt daartegenover dat God met de prediking verschillende intenties heeft ten aanzien van enerzijds de uitverkorenen en anderzijds de verworpenen. Wanneer God zegt dat Hij geen lust heeft in de dood van de goddeloze, maar in diens bekering en leven, spreekt Hij op conditionele wijze. Hij geeft daarmee niet aan wat Hij besloten heeft in zijn verborgen raad, maar verklaart alleen hoezeer Hij bereid is zich te ontfermen over hen die zich oprecht tot Hem bekeren. De kerkhervormer zag het kennelijk niet als een probleem om in de prediking alle hoorders op te roepen tot geloof in Gods goedgunstigheid jegens hen om Christus' wil, terwijl hij toch in zijn systematische bezinning poneerde dat God zijn zaligmakende genade alleen voor de uitverkorenen onder de hoorders heeft gereser- 
veerd en dus voor de verworpenen onder de hoorders (meest verbondskinderen) niet werkelijk de genadige en verzoende Vader wilde zijn. Calvijn geeft er geen blijk van deze spanning tussen predestinatie en prediking als problematisch te hebben ervaren. Hij meende Christus welmenend aan heel de gemeente te kunnen aanbieden op basis van de conditionele structuur van het verbond en van de uitwendige roeping. In zijn preken (Rouwendal onderzocht de in 1550 en 1551 gehouden preken over Micha en een aantal preken over Genesis uit de jaren 1559 en 1560) noemt Calvijn Gods verborgen raad met de praedestinatio gemina niet, maar beperkt hij zich tot het spreken over Gods geopenbaarde wil. Opvallend is dat in veel preken de leer van verkiezing en verbond in het geheel niet aan de orde komt, behalve wanneer de tekst daar uitdrukkelijk aanleiding toe geeft, en dat de predestinatie dus zeker niet de prediking beheerst. Nergens beperkt Calvijn in deze preken de nodiging tot het heil tot de uitverkorenen. Hij legt veeleer de nadruk op de ootmoed van zondaren die zelfs een voorwaarde lijkt te worden om zich de belofte van het heil te kunnen toe-eigenen. Merkwaardig is overigens dat Calvijn in de onderzochte preken zelden naar Christus wijst als de spiegel van de verkiezing en het voorwerp van het geloof. In dit opzicht zijn de preken minder christocentrisch dan men zou verwachten.

Ook Beza ziet als doel van de prediking enerzijds de redding van de verkorenen en anderzijds de verharding van de verworpenen. Prediking is een middel om zowel verkiezing als verwerping te effectueren. Hoewel predikers weten dat het niet Gods wil is dat alle toehoorders tot bekering zullen komen, dienen zij wel van harte te wensen dat zij zich allen zullen bekeren. In het spreken over de causa van het ongeloof brengt Beza een verfijning aan ten opzichte van Calvijn: Gods besluit tot verwerping is niet een directe oorzaak van het ongeloof van de verworpenen, maar verordent de oorzaken van ongeloof, die in eerste instantie in de mens zelf liggen. Wat betreft de plaats van de predestinatie in de prediking is de overeenkomst tussen Calvijn en Beza groot. Ook Beza is van overtuiging dat de predestinatie niet voorop geplaatst mag worden en dat nooit individuele personen als verworpenen mogen worden aangewezen. Ook hem is het erom te doen zowel aan Gods soevereiniteit als aan de menselijke verantwoordelijkheid het volle pond te geven.

Een en ander klinkt goed, maar toch blijf ik hier met een onbevredigend gevoel zitten. Dat wordt versterkt wanneer we de gedachten van Franciscus Turrettini (1623-1687) hierbij betrekken. Hij bestrijdt in de periode van de hoge orthodoxie met kracht de theologen uit Saumur, met name Amyraut. De mede door hem opgestelde Formula Consensus (1675) was bedoeld als stevige grendel op de deur die de invloed vanuit Saumur op de theologie in Zwitserland en Genève moest voorkomen en tegengaan. In zijn Institutio 
Theologiae elencticae stelt Turrettini expliciet dat Christus stierf voor dezelfde personen voor wie Hij is opgestaan en voor wie Hij voorbede doet bij de Vader in de hemel. Hij ontkent dat iedereen ertoe opgeroepen mag worden te geloven dat Christus voor hem of haar persoonlijk stierf. Je mag dat immers alleen zeggen wanneer je eerst tot oprecht geloof en bekering bent gekomen. Evenals Beza beperkt ook Turrettini het wezen van het verbond (dat hij onderscheidt van de bredere bediening van het verbond) tot de uitverkorenen. Hij bindt verkiezing, verzoening en verbond nauw aan elkaar. God heeft niet de intentie dat allen die de evangelieprediking horen behouden zullen worden. Van Christus' tranen over Jeruzalem zegt hij dat het weliswaar echte tranen waren, maar dat Jezus niet weende als God, maar als menselijke persoon. Zijn tranen zeggen niets over de verborgen wil of raad van God maar des te meer over zijn geopenbaarde, bevelende wil. Als God zou Jezus het volk van Israël uiteraard hebben kunnen bekeren en redden als Hij dat gewild had. Maar God heeft bepaald dat het ongelovige volk alleen de externe roeping zou ontvangen en niet de inwendige roeping. De tranen van Jezus zijn er dus geen bewijs van dat God de intentie had Jeruzalem te redden, maar zij leggen er getuigenis van af dat God zich verheugt in geloof en bekering! Hier moeten we toch de ernstige vraag stellen of dit spreken bijbels-theologisch verantwoord is? In de bezinning op de godsleer doen we er goed aan - dit in navolging van hoe Gijsbert van den Brink en Kees van der Kooi hierover schrijver in hun Christelijke Dogmatiek - in te zetten bij Gods toewendingseigenschappen en vervolgens Gods verhevenheidseigenschappen in dat licht te bezien. God is betrouwbaar in zijn openbaring in Christus, dus Jezus' tranen over Jeruzalem zijn voluit Gods tranen. God heeft werkelijk en ten volle gewild dat Jeruzalem zich zou bekeren, de onwil ligt volledig aan de kant van de hoorders en getuigen van Jezus' boodschap. Maar wordt in heel dit gebeuren dan niet Gods raad vervuld en blijft God ook hierin niet soeverein de regie voeren? Jazeker, maar wij behoeven niet te doorgronden hoe we deze tegenstelling kunnen oplossen. Hier stokt ons denken en geven we over het onbegrepene God de eer.

Een laatste opmerking nog over Benedict Pictet, een oomzegger van F. Turrettini. Hij leefde in de periode waarin de gereformeerde orthodoxie haar overheersende positie aan de academie van Genève begon te verliezen. Een jaar na de dood van Pictet, 1725, werd aan de Geneefse academie niet langer instemming gevraagd met de Canones van Dordrecht en in 1742 werd het zelfs per decreet verboden in de prediking bepaalde leerstukken aan te roeren. In plaats daarvan moest alle nadruk vallen op de heiliging van het leven. Nog weer later, in 1817, verbood de Compagnie des pasteurs aan César Malan en Robert Haldane c.s. over onderwerpen als de verkiezing te preken. Tegenover 
deze tendensen wilde Pictet juist trouw zijn aan de erfenis van zijn voorgangers en bleef hij de theologie van Amyraut c.s. bestrijden (hoewel hij in de polemiek zijn focus verlegde naar de aanhangers van andere religies). Hij legt vergeleken met Turrettini milde accenten, maar dat wil niet zeggen, zoals Rouwendal enigszins suggereert, dat hij de leer van de predestinatie niet belangrijk vond. Zijn irenische inzet voor eenheid met de lutheranen werd positief gemotiveerd door hoogschatting van wat gereformeerden en lutheranen in Christus verbond, en niet ingegeven door een devaluatie van de belijdenis van de verkiezende God. Pictet was wellicht zijn tijd vooruit in zijn afweging dat er meer is dat oprechte belijders van Christus verbindt dan wat hen scheidt, ook al zijn de blijvende verschilpunten niet te onderschatten. 